\title{
Trophic and reproductive ecology of a species of Hemibrycon (Pisces: Characidae) in Tinajas creek, Quindío River drainage, upper Cauca basin, Colombia
}

\author{
César ROMÁN-VALENCIA ${ }^{1}$ \& Alvaro BOTERO ${ }^{2}$ \\ Universidad del Quindío, Laboratorio de Ictiología, A.A. 460 Armenia, Quindío, Colombia. E- \\ Mail: ${ }^{1}$ croman@uniquindio.edu.co; ${ }^{2}$ albotero33@yahoo.com
}

\begin{abstract}
We studied trophic and reproductive ecology of a new endemic species of characid fish Hemibrycon sp., from Tinajas Creek, Quindío River drainage, upper Cauca basin, Colombia. The diet consisted primarily of Diptera (Tipulidae and Chironomidae), Hymenoptera (Formicidae) and Coleoptera (Dytiscidae), but it also eats algae (Clorophyta) and seeds. Alochtonous food items are important factor for this species. The species reproduces in both the wet and dry seasons. During September-October they store lipids in their celomic cavity. Fecundity is low (405 oocytes) and the sex ratio is 1:2.28, with a predominance of males. Hemibrycon sp. is syntopic with:

Cetopsorhandia boquillae, Astyanax aurocaudatus, Trichomycterus caliense, and Poecilia caucae. Physical and chemical of data of their habitat are included.
\end{abstract}

Key words: Hemibrycon sp., Characid fish, ecology, reproduction, diet.

The Characidae are distributed from the Rio Grande, in the southern part of Texas, through Central America, down to $41^{\circ}$ south latitude in Chile and Argentina (Cala, 1990). This family is of the most important of the Neotropical icthyofauna in terms of biomass and species number (Kramer, 1978). Characids are dominant fishes in density and species quantity from the entire Colombian basin (Cala, 1990), are small-sized, silvered, laterally compressed, diurnal in habitats and usually non-specific in their trophic behavior (Machado-Allison, 1987).

The approximately 18 species of the genus Hemibrycon are distributed in Peru, Ecuador, Colombia, Panama, Venezuela, Trinidad and Surinam (Roman-Valencia, 2001). The species we studied, can be considered as endemic of this drainage and has been reported as a novelty within genus (Roman-Valencia et al., in press). Since little information is available about the ecology of this Hemibrycon species (Roman-Valencia et al ., in press). We decided to study the trophic and reproductive ecology to provide knowledge crucial to promote the conservation of its habitat, which is now a tourist attraction, and as a result, is undergoing many change to the natural ecosystem.

\section{MATERIALS AND METHODS}

Fish were collected monthly between February 2003 and January 2004 at Quebrada
Tinajas, Rio Quindio Tributary, upper Rio Cauca, $4^{\circ} 36^{\prime} 57^{\prime \prime} \mathrm{N} \& 75^{\circ} 36^{\prime} 35^{\prime \prime} \mathrm{W}, 1712 \mathrm{~m}$ a.s.l. Collecting took place during both the dry (February-March, July-August) and wet seasons (April-June, September-December).

Fish were captured using a drag net, a seine and preserved in ice, in situ; then were carried to the Laboratory of Ichthyology, Department de Biology, Universidad del Quin-dio, Armenia, Colombia (IUQ), where they are now deposited.

120 specimens were examined, $51.5 \mathrm{~mm}$ of mean standard length (25.5-75.5 mm SL). Fish were measured, weighed and cut along their major axis to remode their digestive tracts and gonads. 116 stomach contents were analyzed, using occurrence index, numeric index (Hynes, 1950; Hyslop, 1980), volumetric analysis (Pedley \& Jones, 1978; Capitoli, 1992), and an importance index (Oda \& Parrish, 1981), were I= (Occurrence \% * Volume \%)/100.

Then Principal Components statistical analysis was applied, considering volume, quantity and frequency as variables and different items found on the stomachs of the individuals. To standardizer frequency, volume and quantity values this procedure was followed: for each variable its mean value and its standard deviation were calculated, then mean value was taken from each individual value and the result was divided by the standard deviation, all of this was done to 
make it possible to compare between different sized fishes.

The analysis of feeding activity $(R)$ was based on the quotient of stomach content (Ghazai et al, 1991), where $\mathrm{R}=\mathrm{We} / \mathrm{Wt}$ * 100 (We: Stomach weight (g) and Wt: Individual weight (g). Using field information about diet from earlier work, RomanValencia (pers. com.), Román-Valencia \& Ruiz (2005), Román-Valencia et al. (2003) and of course those from present work, trophic diversity was calculated, by Shannon-Winner index cited in Ferris \& Salas (1994), between Hemibrycon sp.,

Bryconamericus caucanus, Cetopsorhamdia boquillae, Hyphessobrycon poecilioides, Roeboides dayi and Astyanax aurocaudatus. The units with the diversity is measured come from the infor-mation theory and its depend on the type of used logarithms, in our case bits for logarithm base 2 (Magurran, 1989).

Morisita overlapping diet index was applied (CH) cited by Granado (1996) and Spearman Correlation Range (Rs) (Fritz 1974) to compare between the diet Hemibrycon sp., Astyanax aurocaudatus (Roman-Valencia \& Ruiz, 2005) and the one of the Cetopsorhandia boquillae (Román-Valencia \& Giraldo pers. com.), to calculate previous indexes those items that could not be quantified as discrete units were not used.

To calculate the Gonadosomatic Index (RGS) (Vazzoler, 1996) the following equation was used: $\mathrm{RGS}=\mathrm{Wo} / \mathrm{Wc}^{\star} 100$, where, $\mathrm{Wc}=\mathrm{Wt}-\mathrm{Wo}$, and $W o=g o n a d$ weigh $(g), W t=I n d i v i d u a l$ weigh with internal organs $(\mathrm{g})$ and $\mathrm{Wc}=$ body weigh $(\mathrm{g})$ without internal organs. Size at maturity was determined using a graphic statistical method and the sex ratio was tested by Chi-Cuadrado (Sokal \& Rohlf, 1995) and the Spearman Correlation Range was used to determine diet season and variation as it was proposed by Ortaz (2001). Statisgraphics plus 5.0, Statistix 7.0 and Krebs 0.1 (Windows) were used for statistical processing.

Physical and chemical variables were recorde thus: Water color and substrate by direct observation, dissolved oxygen, and saturation of oxygen by electrode method, $\mathrm{pH}$ with electrometric method ( $\mathrm{pH}$ meter), width and depth of the creek with measuring tape (decameter), to establish the variation along time of these variables a Variation Coefficient (\% CV) was applied.

Finally, two water samples were taken, during dry season (March) and the other in wet season (May). To be analyzed for Biochemical Oxygen Demand (DBO), Dissolved Oxygen using Winkler Method, Alkalinity, hardness, dissolved and Chlorates by APHA Standard Methods (1992).

\section{RESULTS}

\section{Habitat}

Hemibrycon sp. inhabit Tinajas Creek, which has an average width of $-1.50 \mathrm{~m}$, and $0.4 \mathrm{~m}$ average depth. its riversides are usually covered by a secondary forest layer composed of Caña Brava (Poaceae) and Heliconias (Heliconia sp), Guadua angustifolia and agricultural systems like: coffee (Coffea arabiga) and plantain (Musa paradisiaca). The substrate texture of the river basin is a mixture of sand, stones and decomposed organic matter. Water is crystalline but in the wet season it turns brown, superficial temperature is $18.2{ }^{\circ} \mathrm{C}$, with low variation coefficient (17.9-19.7 ${ }^{\circ} \mathrm{C}$, \%CV de 7.17), and atmospheric temperature is $18.52{ }^{\circ} \mathrm{C}(17.5-18.5$ ${ }^{\circ} \mathrm{C}$; \%CV 2.57). The latter presented almost no change during the study. Dissolved oxygen presented a high and stable value during the observation period, $7,18 \mathrm{mg} / \mathrm{l}$ medium value (6.13-8.2 $\mathrm{mg} / \mathrm{l} \% \mathrm{CV} 2.57$ ), and the mean oxygen saturation percentage was $90.71 \%$ (77.8- 107.5 \%). $\mathrm{pH}$ values near 7 (6.7-7.85 \%CV 7.2) were found (Table 1). DBO and DQO presented almost no variation between wet and dry seasons (Table 2). But other items did change alkalinity $(24 \mathrm{mg} / \mathrm{I}$ $\mathrm{CaCO} 3$ in dry and $42 \mathrm{mg} / \mathrm{l} \mathrm{CaCO} 3$ in wet), total solids (71 mg/l in ray, and $98 \mathrm{mg} / \mathrm{l}$ in wet), dissolved solids (67 mg/l in dry, $94 \mathrm{mg} / \mathrm{l}$ in wet); and chlorides $(37 \mathrm{mg} / \mathrm{l} \mathrm{Cl}$ in dry $200 \mathrm{mg} / \mathrm{l} \mathrm{Cl}$ in wet) (Table 2). Augmentation during wet season on past items could be related with erosion and anthropic processes occurring at this basin; it can be said that valves presented are characteristically for this kind of habitat of Neotropical highlands.

Hemibrycon sp. Is syntopic with: Cetopsorhamdia boquillae, Astyanax aurocaudatus, Trichomycterus caliense, and Poecilia caucana.

\section{Trophic ecology}

Hemibrycon sp. possess a stomach that is longer (mean $10.3 \mathrm{~mm}$ ) than wide (mean 5.34 $\mathrm{mm}$ ), located in the anterior part of the celomic cavity surrounded by other organs. Four to nine (mean 5) pyloric cecae are located at the front part of the stomach.

Hemibrycon sp. stomach contents showed a wide diet spectrum of 52 items (Table 3 ). The most consumed items were: diptera (Chironomidae, Branchycera, Ceratopogonidae, Nematocera), insect pieces, seeds, plant material and Hymenoptera of family Formicidae. The numeric analysis (Table 3 ) which indicates the importance of each item selected, gave these results: diptera (Tipulidae, Chironomidae y Branchycera), insects 
Table 1. Physical and chemical data of Hemibrycon sp. from Tinajas creek.

\begin{tabular}{lcccccc}
\hline Month/variable & $\begin{array}{c}\text { Atmosphere } \\
\text { temperature } \\
{ }^{\circ} \mathrm{C}\end{array}$ & $\begin{array}{c}\text { water } \\
\text { temperature } \\
{ }^{\circ} \mathrm{C}\end{array}$ & $\begin{array}{c}\text { Disolved } \\
\text { oxygen } \\
\mathrm{mg} / \mathrm{l}\end{array}$ & $\begin{array}{c}\text { Saturation } \\
\text { of oxigen } \\
\%\end{array}$ & $\mathrm{pH}$ & $\begin{array}{c}\text { Color } \\
\text { of water }\end{array}$ \\
\hline Mar. & 18.9 & 18.8 & 8.2 & 107.5 & 7.75 & gray \\
Apr. & 18 & 18.1 & 7.5 & 96.61 & 7.85 & \\
Jun. & 18.3 & 18 & 6.13 & 78.2 & 7.78 & \\
Jul. & 18.2 & 17.5 & 7.85 & 77.8 & 6.76 & Transparent \\
Ago. & 17.9 & 17.8 & 7.53 & 98.9 & 7.06 & Coffee \\
Sep. & 17.8 & 17.3 & 7 & 87.8 & 6.56 & Transparent \\
Oct. & 18.8 & 18.1 & 6.96 & 89.3 & 6.88 & Transparent \\
Nov. & 19.7 & & & & 6.72 & Transparent \\
Dec. & 18.4 & 17.7 & 6.9 & 89 & 7.31 & Transparent \\
Jan. & 18.4 & 18.5 & 7.1 & 94 & 6.94 & Transparent \\
Averange & 18.52 & 18.2 & 7.18 & 90.71 & 7.09 & \\
Coefficient of & 7.17 & 2.57 & 8.32 & 9.98 & 7.2 & \\
$\quad$ variation (\%CV) & & & & & & \\
\hline
\end{tabular}

Table 2. Physical and chemical data of Hemibrycon sp. from Tinajas creek, Quindio River, upper Cauca River, Colombia.

\begin{tabular}{|c|c|c|}
\hline Variable/season & Summer march de 2003 & Wet May of 2003 \\
\hline water temperature $\left({ }^{\circ} \mathrm{C}\right)$ & 16 & 17.6 \\
\hline Atmosphere temperature $\left({ }^{\circ} \mathrm{C}\right)$ & 15.2 & 19.6 \\
\hline Saturation of oxigen & 91 & 97 \\
\hline Disolved oxygen $(\mathrm{ml} / \mathrm{l})$ & 7.4 & 8 \\
\hline $\mathrm{pH}$ & 7.36 & 7.7 \\
\hline Relative humidity (\%) & 92 & 93 \\
\hline Sustrate & Mud and detritus & Sand and detritus \\
\hline Color & Transparent & Coffee \\
\hline Velocity of the running $(\mathrm{m} / \mathrm{s})$ & 0.21 & 0.033 \\
\hline Wide $(\mathrm{m})$ & 2.95 & 3.06 \\
\hline Profundity (m) & 0.6 & 0.3 \\
\hline D.B.O (mg/l) & 1.1 & 3.8 \\
\hline D.Q.O (mg/l) & 28 & 17.2 \\
\hline Total Hardness (mg/l CaCO3) & 20 & 26 \\
\hline Calcium Hardness (mg/l CaCO3) & 17 & 10 \\
\hline Magnesium Hardness (mg/l CaCO3) & 3 & 16 \\
\hline Alkalinity (mg/l CaCO3) & 24 & 42 \\
\hline Acidity (mg/l) & 2 & 10 \\
\hline Total solid (mg/l) & 71 & 98 \\
\hline Disolved solids (mg/l) & 67 & 94 \\
\hline Suspended solids (mg/l) & 4 & 4 \\
\hline Chlorine $(\mathrm{mg} / \mathrm{l} \mathrm{Cl})$ & 37 & 200 \\
\hline
\end{tabular}

parts, and seeds. Volumetric analysis (Table 3) shows a tendency for: diptera (Branchycera and Tipulidae), insects parts, chlorophytas algae, seed, pant material and orthoptera: tetrigidae. The importance index showed that dominant items were again diptera of the family Tipulidae and Branchycera, but also insects parts and seed (Table 3).

Principal component analysis gave a first axis with values of that the main proper values were of 2.50 which accounted for over $83.65 \%$ of the variation (Table 4). This data was used as criteria 


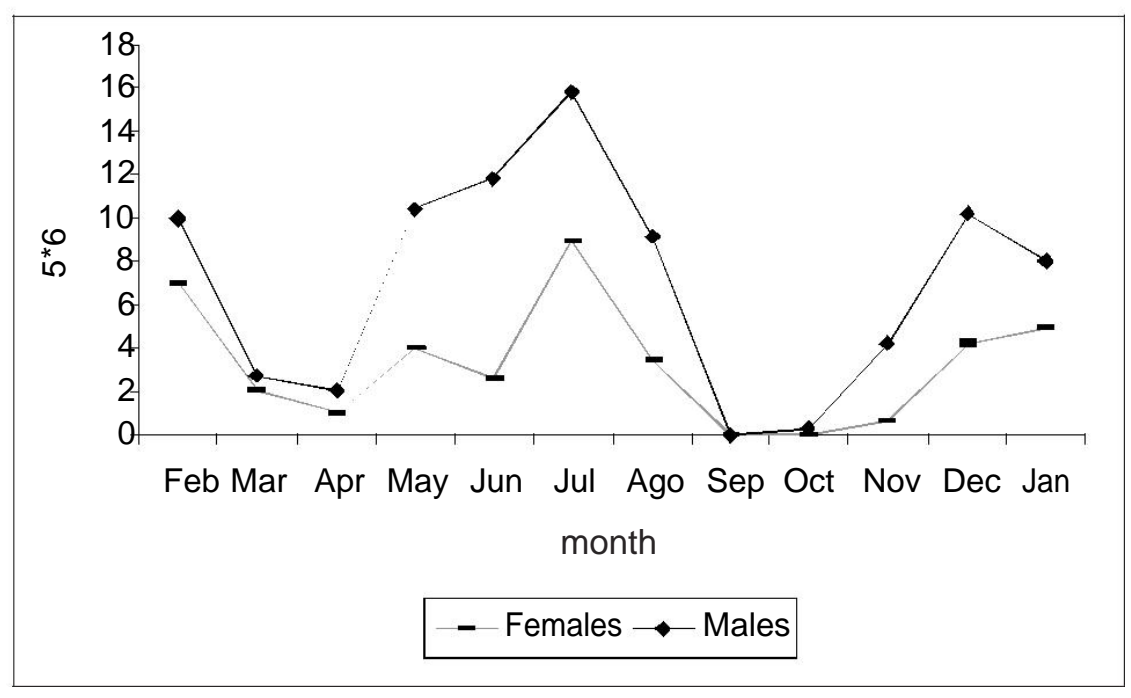

Fig. 1 Gonosomatic Index (RGS) mean of females and males in Hemibrycon sp., in the Tinajas creek, Feb. 2003 - Jan. 2004.

for only considering the first main component where its alimentary tendency index was: $0.520122^{\star}$ standard number $+0.603168^{\star}$ standard volume $+0.604699^{*}$ standard frequency. Thus essential items of the diet of Hemibrycon $s p$. were insects fragments, clorophyceas algae, and larva of diptera: muscidae, empididae, tipulidae, nematocera.

Feeding activity is diurnal asinferred from the digestion condition of the food items examined. Hemibrycon sp. Feeds on organisms that are found at the bottom of the water column, as well as adult insects of alochtonous origin that fall inside this environment. Important differences were not observed between the wet and dry seasons changes diet $(R s=0.8 p=0.0001)$, which suggests that resources remain mostly unchanged in the environment.

The alimentary spectrum of fish that share the same habitat with the studied species and other characids, presented a high trophic diver-sity with tendency to euophagy: Hemibrycon sp.

4.31 bits, Hemibrycon boquiae 3.56 bits, Bryconamericus caucanus 3.24 bits, Hyphessobrycon poecilioides 2.84 bits, Roeboides dayi 3.51 bits and Astyanax aurocaudatus 3.1 bits. The data by the Morisita index $(\mathrm{CH})$ when comparing the ali-mentary preferences of the species with the ones of sintopic species, the data were low as well as the Sperman quotient of correlation, which also were low (Rs) and it registered a non significative correlation of the variables: between Hemi-brycon sp. -Astyanax aurocaudatus $(\mathrm{CH}=0.0006$ y Rs $0.54 \mathrm{p}=0.01)$ and Hemibrycon sp. -Cetopsor-hamdia boquillae $(\mathrm{CH}=0.005$ y Rs $0.03 \mathrm{p}=0.1)$.
A significative and positive correlation was found between the standard length and the intestine length $(r=0.69, \quad l i=5.35392+$ $0.629008 * \mathrm{l}, \mathrm{n}=75$ ). A non-significant and positive correlation between the weight of the stomach and the standard length $(r=0.48, n=80)$; and the relationship between standard length and the total weight was $(r=0.67$, wt $=-4.38232+$ $0.137985 *$ Is $n=75)$.

\section{Reproductive characteristics}

Previous analysis of the reproductive aspects of the Hemibrycon sp. indicate that the Gonodosomatic index (RGS) obtained its maximum values with females in June-July and DecemberFebruary, with spawning occurring in March and August (Fig. 1). Males the maximum valvues of RGS were collected during Mayo-Julio and November-January. The minimums occurred in February-April and the July-August (Fig. 1). In September and October specimens were found with empty gonads and high amounts of lipids inside the body cavity.

The minimum size of maturity was $40 \mathrm{~mm} \mathrm{SL}$ for females and $30 \mathrm{~mm} \mathrm{SL}$ for males, $50 \%$ of the population reaches full gonad deve-lopment for females when they are $53 \mathrm{~mm}$ standard length and for males $50 \mathrm{~mm}$ (Fig. 1). The mean oocyte count was 445 (range 168-741) with a mean diameter $0.74 \mathrm{~mm}(0.85-0.5 \mathrm{~mm})$. During this study females were more numerous, and comprised $68.8 \%$ of the samples, significantly greater with a 1:2.28 (X2 =0.0098, GL 1 á 0.005). No sexual dimorphism was observed. 
Table 3. Stomach contents of Hemibrycon sp., in Tinajas creek, Quindio River. Upper Cauca River, Colombia. N: \% Numerical; F: \% frequency; V:\% volume; I: importance índex. pc: principal component. A: adult; L:Larva

\begin{tabular}{|c|c|c|c|c|c|}
\hline Contents & 1 & $\% \mathrm{~N}$ & $\% \mathrm{~V}$ & $\% \mathrm{~F}$ & $\mathrm{pc}$ \\
\hline Diptera (A) & 0.0026 & 0.312 & 0.820 & 1.420 & -0.275 \\
\hline Diptera part (L) & 0.0112 & 1.363 & 0.820 & 1.136 & -0.273 \\
\hline Diptera part (A) & 0.0001 & 0.195 & 0.075 & 0.568 & -0.485 \\
\hline Diptera (L) & 0.0003 & 0.195 & 0.149 & 0.852 & -0.432 \\
\hline Diptera Orthorrapha (L) & 0.0003 & 0.195 & 0.168 & 0.568 & -0.476 \\
\hline Diptera orthorrapha nematocera (L) & 0.0024 & 0.545 & 0.438 & 1.705 & -0.253 \\
\hline Diptera Psychodoidea (L) & 0.0003 & 0.156 & 0.205 & 0.568 & -0.475 \\
\hline Diptera Psychodoidea (A) & 0.0001 & 0.039 & 0.186 & 0.284 & -0.528 \\
\hline Diptera ceratopogonidae (L) & 0.0018 & 0.351 & 0.507 & 1.989 & -0.21 \\
\hline Diptera simulidae (L) & 0.0015 & 0.584 & 0.261 & 1.136 & -0.359 \\
\hline Diptera tipulidae $(\mathrm{L})$ & 0.0185 & 1.948 & 0.950 & 3.125 & 0.086 \\
\hline Diptera culicidae (L) & 0.0000 & 0.039 & 0.056 & 0.284 & -0.540 \\
\hline Diptera chironomidae $(\mathrm{L})$ & 0.0073 & 1.130 & 0.646 & 6.534 & 0.571 \\
\hline Diptera orthorrapha brachycera (L) & 0.0231 & 1.675 & 1.379 & 4.545 & 0.341 \\
\hline Diptera Empididae (L) & 0.0050 & 0.662 & 0.755 & 1.989 & -0.174 \\
\hline Diptera stratiomydae (L) & 0.0000 & 0.039 & 0.075 & 0.568 & -0.492 \\
\hline Diptera tabanidae $(\mathrm{L})$ & 0.0010 & 0.234 & 0.447 & 1.420 & -0.312 \\
\hline Diptera cyclorrapha (L) & 0.0052 & 0.779 & 0.671 & 2.841 & -0.038 \\
\hline Diptera cyclorrapha ( A) & 0.0001 & 0.078 & 0.093 & 0.568 & -0.488 \\
\hline Diptera muscidae (L) & 0.0034 & 0.506 & 0.663 & 3.125 & -0.005 \\
\hline Hymenoptera A & 0.0006 & 0.156 & 0.354 & 1.136 & -0.369 \\
\hline Hymenoptera formicidae A & 0.0027 & 0.312 & 0.857 & 1.705 & -0.226 \\
\hline Hymenoptera parts (A) & 0.0079 & 0.935 & 0.848 & 1.136 & -0.290 \\
\hline Himenóptera vespidae (A) & 0.0002 & 0.039 & 0.466 & 0.284 & -0.503 \\
\hline Hemiptera mesoveliidae (A) & 0.0004 & 0.039 & 0.969 & 0.284 & -0.458 \\
\hline Orthoptera (A) & 0.0002 & 0.039 & 0.466 & 0.284 & -0.503 \\
\hline Orthoptera tetrigidae $(\mathrm{A})$ & 0.0020 & 0.117 & 1.751 & 0.568 & -0.339 \\
\hline Coleotera (L) & 0.0002 & 0.078 & 0.242 & 0.568 & -0.475 \\
\hline Coleotera dytiscidae (A) & 0.0016 & 0.195 & 0.820 & 1.136 & -0.326 \\
\hline Coleoptera psephenidae (L) & 0.0043 & 0.857 & 0.503 & 0.852 & -0.370 \\
\hline Coleoptera parts & 0.0046 & 0.623 & 0.736 & 1.420 & -0.269 \\
\hline Ephemeroptera (nymph) & 0.0000 & 0.039 & 0.093 & 0.284 & -0.536 \\
\hline Ephemeroptera part (nymph) & 0.0002 & 0.273 & 0.056 & 1.420 & -0.345 \\
\hline Trichoptera (L) & 0.0000 & 0.039 & 0.009 & 0.284 & -0.543 \\
\hline Trichoptera Hydropsichidae (larva) & 0.0003 & 0.156 & 0.205 & 0.852 & -0.429 \\
\hline Collembola Sminthuridae & 0.0001 & 0.039 & 0.242 & 0.284 & -0.523 \\
\hline Annelida & 0.0003 & 0.078 & 0.335 & 0.284 & -0.512 \\
\hline Aracnea (At) & 0.0000 & 0.039 & 0.112 & 0.284 & -0.534 \\
\hline Neuroptera & 0.0005 & 0.078 & 0.652 & 0.284 & -0.484 \\
\hline Odonata (nymph) & 0.0004 & 0.039 & 0.112 & 0.284 & -0.534 \\
\hline Insect part & 26.3582 & 81.262 & 32.436 & 18.750 & 9.0154 \\
\hline Algas: clorophyceas & 0.0000 & 0.000 & 8.160 & 4.830 & 0.915 \\
\hline Fish scale & 0.0000 & 0.039 & 0.024 & 0.284 & -0.542 \\
\hline Epithelium tissue of fish & 0.0000 & 0.039 & 0.093 & 0.284 & -0.536 \\
\hline Stones & 0.0003 & 0.234 & 0.116 & 0.852 & -0.433 \\
\hline Plant material & 0.0000 & 0.000 & 1.025 & 1.136 & -0.317 \\
\hline Fruits & 0.0004 & 0.117 & 0.354 & 0.852 & -0.417 \\
\hline Oocyte & 0.0000 & 0.039 & 0.019 & 0.284 & -0.543 \\
\hline Seed & 0.0768 & 3.078 & 2.497 & 4.830 & 0.549 \\
\hline Digested material & 0.0000 & 0.000 & 36.088 & 19.034 & 5.696 \\
\hline Total & & 100 & 100 & 100 & \\
\hline
\end{tabular}


Table 4. Variation percentage and mean values of the main component analysis of the alimentary items of Hemibrycon sp. from Tinajas creek, Quindio River. upper Cauca River. Colombia.

\begin{tabular}{cccc}
\hline Component number & Eigenvalue & Porcent of Variance & Cumulative percentage \\
\hline 1 & 2.5 & 83.6 & 83.6 \\
2 & 0.44 & 14.7 & 98.3 \\
3 & 0.05 & 1.68 & 100 \\
\hline
\end{tabular}

\section{DISCUSSION}

Species are not pieces of a machine with fixed properties, nor constants populations rather, the same species responds differenty in different places or moments to the challenges of survival (Margalef, 2002). Most tropical fish do not usually show trophic specializations and often change their diet as their biotype changes or according with the fluctuation of the seasons (Lowe-McConnell, 1987). This is the case for Hemibrycon sp., given that it does not only feed on aquatic insects but also on alochtonous material (Ara-nnea, Himenoptera, vegetal part and beetles Coleoptera) that fall occasionally into the water, during the dry and wet seasons. This response is similar to that found by Román-Valencia et al., (pers. com.) for Bryconamericus caucanus and

Hemibrycon boquiae, where the only differences in the food was the presence of alochtonous material (such as Hymenoptera (Formicidae), terrestrial beatles, Annelida and Hemiptera. It is accurate to say that Hemibrycon sp. then, is a generalist species.

The presence of bushy remnants along the shores of Tinajas creek provides more opportunity for vegetal components and forest related arthropofauna which Hemibrycon sp. Exploits. This can be noticed by the presence of terrestrial insects, vegetal material, seeds and fruits which are not part of the aquatic environment. LoweMcConnell (1987) noted the great importance of alloctonous material for the fish that dwell in fast flowing rivers lined with a flora and fauna foreign to the aquatic medium.

Intestinal length relative to body length is yet another indication of diet: herbivores tend to have a relative longer intestine, than carnivores (Kramer \& Bryant, 1995). With the ratio in carnivores less than one (Bussing, 1993). This is confirmed for Hemibrycon sp., and allows us to classify it as a carnivore and insectivore, taking into account that its diet contains mainly insects and algae, the vegetable material (plants, fruits and seeds) fruits are only 4 of the 52 items (Table 3), compared to 45 insect items. This feature has been reported for other characids like Creagrutus brevipinnis (Román-Valencia, 1998), Roeboides dayi (Román-Valencia et al., 2003), Argopleura magdalenensis (Román-Valencia \& Perdomo, 2004), Bryconamericus caucanus and Hemibrycon boquiae (Giraldo \& Román-Valencia pers. com.), all from upper Cauca river.

Unidentified nematodes were found in the stomachs of Hemibrycon sp.; as well as Bryconamericus caucanus (Román-Valencia \& Muñoz, 2001), Argopleura magdalenensis (Román-Valencia \& Perdomo, 2004) and Hemibrycon boquiae (Roman-Valencia et al., per. com.), the presence of apparently undigested nematodes inside the fishe's gut means that these nematodes were endoparasites of the Hemibrycon sp., these endoparasites are of indirect cycle in adult fishes (Granado, 1996), that can affect or regulate the

Hemibrycon sp. populations.

Hemibrycon sp. has lower fecundity (445 oocytes) than other characids with wider geographical range like: Bryconamericus caucanus with 3759 oocytes (Román-Valencia \& Muñoz, 2001; Giraldo \& Román-Valencia, per. com.),

Bryconamericus galvisi 1391 oocytes (RománValencia \& Muñoz, 2001) and Creagrutus brevipinnis 613 oocytes (Román-Valencia, 1998). But similar or fewer results were found in other cha-racids who have same geographical range, like: Hemibrycon boquiae 376 oocytes (RománVa-lencia et al., pers. com.), Roeboides dayi 305 oo-cytes (Román -Valencia et al., 2003), Astyanax aurocaudatus 181 oocytes (RománValencia \& Ruiz, 2004).

Progressive increases of Gonosomatic Index (RGS) shows the maturity level of the species which suddenly drops marking egg-laying time (Kaiser, 1973; Htun -Kan, 1978). Hemibrycon sp. reproduce when the dry season is ending (August) and again when the wet season is beginning (February-April). Similar results were found on other upper Cauca characids as: Roeboides dayi (Román-Valencia et al., 2003), Creagrutus brevipinnis (Román-Valencia, 1998) and Bry-conamericus caucanus (RománValencia \& Muñoz, 2001). Confirm what was said by Lowe- 
McConnell (1987), these features support that the few estimations of reproductive cycles at small basins show that there different reproductive strategies coexist, that includes spawns at dry season or at wet season or throughout the year. September-October individuals presented fattissue and not gonads, so they when preparing themselves for the next reproductive event.

The Shannon-Wiener diversity index gives an approximation of trophic specialization values reflect europhagic behaviour of predators (Ferriz \& Salas, 1994), it works for Hemibrycon sp.

Hemibrycon boquiae, Bryconamericus caucanus, and Astyanax aurocaudatus; similar results were obtained for Argopleura magdalenensis (RománValencia \& Perdomo, 2004). This trophic diversification let species be not -specialized and opportunistic and this behavior reduced inter and intraspecific competition, and favors differential usage of resources (Ferriz \& Salas, 1994). For the sake of last considerations is why it can be said that Hemibrycon sp. is an opportunistic and eu-rophagic species.

Hemibrycon sp. present little or no competition with Astyanax aurocaudatus or Cetopsorhamdia boquillae as concerns feeding resources, because the Morisita index $(\mathrm{CH})$, resulted in a non- significant, less than 0.6 (sensus Zaret \& Rand, 1971, in Herrera \& López, 1997); the same was shown by Correlation Spearman range (Rs); to conclude that food is a mechanism of ecological segregation for syntopic species that could compete for resources inside the environment (Hemibrycon sp., A. aurocaudatus and $C$. boqui-Ilae), even though their diets are composed of high numbers of macroinvertebrates, differences in the exploitation method because $A$. auro-caudatus eats more alternative items like alochtonous seeds and fruits (Román-Valencia \& Ruiz, 2004), C. boquillae, feeds at late afternoon until night and prefers Trichoptera, Ephe-meroptera, and Odonata (Román-Valencia \& Giraldo, pers. com.), and Hemibrycon sp. prefers diptera and insect of alochtonous origin such as Hymenoptera and they search and catch their prey during daylight also, they have a wider alimentary spectrum.

\section{ACKNOWLEDGMENTS}

Raquel I. Ruiz C. (IUQ) collaborated in fieldwork and laboratory; Donald C. Taphorn and Jorge Iván Sánchez B. realized corrections, comments and suggestions for the improvement of the manuscript. Maria Dolly Ribera for statistical methods of principal components. IDEA WILD provided equipment of laboratory and field.

\section{BIBLIOGRAPHY}

Apha. 1992. Métodos normalizados para el análisis de aguas potables y residuales. Ediciones Días y Santos, Juan Bravo, 3-A 28006 Madrid, España.

Bussing, A. W. 1993. Fish communities and environmental characteristics of a tropical wet forest river in Costa Rica. Rev. Biol. Trop. 41(3): 791-809.

Cala, P. 1990. Diversidad, adaptaciones ecológicas y distribución geográfica de las familias de peces de agua dulce de Colombia. Rev. Acad. Colomb. Cienc. XVII(67): 726-740.

Capitoli, R. R. 1992. Métodos para estimar volúmenes do conteudo alimentar de peixes e macroinvertebrados. Atlantica, Río Grande 4: 117-120.

Ferriz, R. \& W. Salas. 1994. Relaciones tróficas de los peces de un embalse patagónico, provincia de Neuquén, Argentina. Bioikos Campinas 8(1/2): 7-19.

Fritz, E.S. 1974. Total diet comparison in fishes by Sperman Rank Correlation Coefficents. Copeia (1): 210-214.

Ghazai, A. M., V. Benech \& D. Paugy.1991. L'alimentation de Brycinus leuciscus (Teleostei: Characidae) au Mali: aspects qualitatifs, quantitatifs et comportemental. Ichthyol. Explor. Freshwaters 2(1): 47-54.

Granado, L. C. 1996. Ecología de peces. Secretariado de publicaciones de la Universidad de Sevilla 45, $120 \mathrm{p}$.

Herrera, M. \& H. López. 1997. Relaciones tróficas de los peces del embalse Tamanaco, Guárico, Venezuela. Acta Biol. Venez. 17(3): 59-70.

Htun-Kan, M. 1978. The reproductive biology of the dab Limanda limanda (L) in the North Sea: Gonadosomatic index, hepatosomatic index and condition factor. J. Fish Biol. 13: 369-378.

Hynes, H. B. N. 1950. The food of fresh-water Sticklebacks (Gasterosteus aculeatus and Pygosteus pungitius) with a review of methods used in studies of the food of fishes. J. Anim. Ecol. 19: 36-58.

Hyslop, E. J. 1980. Stomach contents analysis- a review and methods and their application. J. Fish Biol. 17(3): 411-429

Kaiser, C. E. 1973. Gonadal maturation and fecundity of horse mackarel, Trachurus murphy of the coast of Chile. Trans. Amer. Fish. Soc. 102: 101-108.

Kramer, D. I.1978. Reproductive seasonality in the fish of a tropical stream. Ecology 59(5): 976-985.

Kramer, D. L. \& M. J. Bryant. 1995. Intestine length in the fishes of a tropical streams: ontogenetic allometry. Environmental Biology of fishes 42: 115127.

Lowe-Mc Connell, R. H. 1987. Ecological studies in tropical fish communities. Cambridge University Press, Cambridge, $382 \mathrm{p}$

Magurran, E. A. 1989. Diversidad ecológica y su medición. Edic. Vedrá, Barcelona, 200 p.

Machado-Allison, A. 1993. Los peces de los Llanos de Venezuela, un ensayo sobre su historia natural. Universidad Central de Venezuela Caracas. $2^{\mathrm{a}}$. Edic. $143 p$

Margalef, R. 2002. Teoría de los sistemas ecológicos. Alfaomega grupo editor S.A. México D. F. 290 p. 
Oda, D. K. \& J. D. Parrish. 1981. Ecology of commercial snappers and groupers introduced to Hawaiian reefs. Proc. fourth International Coral Reef Symp. 1: 59-67.

Ortaz, M. 2001. Diet seasonality and food overlap among fishes of upper Orituco strem, northern Venezuela. Rev. Biol. Trop. 49(1): 191-197.

Pedley, R. B. \& J. W. Jones. 1978. The comparative feeding behaviour of brown trout, Salmon trutta L. and Atlantic Salmon, Salmon salar L. in Llyn Dwythwch, Wales. J. Fish. Biol. 12: 253-256.

Román-Valencia, C. 1998. Alimentación y reproducción de Creagrutus brevipinnis (Pisces: Characidae) en Alto Cauca, Colombia. Rev. Biol. Trop. 46(3): 783789.

- 2001. Redescripción de Hemibrycon boquiae (Pisces: Characidae), especie endémica de la quebrada Boquía, cuenca Río Quindío, alto Cauca, Colombia. Dahlia (Rev. Asoc. Colomb. Ictiol.) 4: 27-32.

Román-Valencia, C. \& A. Muñoz. 2001. Ecología trófica y reproductiva de Bryconamericus caucanus (Pisces: Characidae). Boll. Mus. Reg. Sci. Nat. Torino 18(2): 459-467.

Román-Valencia, C., A. Botero B. \& R. I. Ruiz. 2003.

Trophic and reproductive ecology of Roeboides dayi
(Teleostei: Characidae) from upper Rio Cauca, Colombia. Boll. Mus. Reg. Sci. Nat. Torino 20(2): 487-496.

Román-Valencia, C. \& A. Perdomo. 2004. Ecología trófica y reproductiva de Argopleura magdalenensis (Pisces: Characidae) en la cuenca alta de los Ríos Cauca y Magdalena, Colombia. Rev. Mus. Argentino Cienc. Nat., n.s. 6(1): 175-182.

Román-Valencia, C. \& R. I. Ruiz. 2005. Diet and reproduction aspects of Astyanax aurocaudatus (Teleostei: Characidae) from the Upper part of the Rio Cauca, Colombia. Dahlia (Rev. Asoc. Col. Ictiol.) 8: 9-17.

Román-Valencia, C. In press. Seven new species of Hemibrycon (Characiformes: Characidae) from the basin of Magdalena river, Colombia. Rev. Biol. Trop. 53

Sokal, R. S. \& D. J. Rohlf. 1995. Biometry. W.H. Freeman and Co., New York, 887p.

Vazzoler, A. E. A. de M. 1996. Biologia da reprodução de peixes teleósteos: teoria e prática. Maringá: EDUEM; São Paulo: SBI, 169 p.

Zaret,T. M. \& A. S. Rand. 1971. Competition in tropical stream fishes: support for the competitive exclusion principle. Ecology 52: 336-342. 